\title{
How Do Immune Cells Support and Shape the Brain in Health, Disease, and Aging?
}

\author{
Michal Schwartz, ${ }^{1}$ Jonathan Kipnis, ${ }^{2}$ Serge Rivest, ${ }^{3}$ and Alexandre Prat ${ }^{4}$ \\ ${ }^{1}$ Department of Neurobiology, Weizmann Institute of Science, Rehovot 76100, Israel, ${ }^{2}$ Center for Brain Immunology and Glia, Department of Neuroscience, \\ University of Virginia, Charlottesville, Virginia 22908, ${ }^{3}$ Neuroscience Laboratory, CHU de Québec Research Center and Department of Molecular Medicine, \\ Faculty of Medicine, Laval University, Quebec City, Quebec G1V 4G2, Canada, and ${ }^{4}$ Neuroimmunology Unit, Center for Excellence in Neuromics, CRCHUM, \\ Université de Montréal, Montreal, Quebec H4A 2B4, Canada
}

For decades, several axioms have prevailed with respect to the relationships between the CNS and circulating immune cells. Specifically, immune cell entry was largely considered to be pathological or to mark the beginning of pathology within the brain. Moreover, local inflammation associated with neurodegenerative diseases such Alzheimer's disease or amyotrophic lateral sclerosis, were considered similar in their etiology to inflammatory diseases, such as remitting relapsing-multiple sclerosis. The ensuing confusion reflected a lack of awareness that the etiology of the disease as well as the origin of the immune cells determines the nature of the inflammatory response, and that inflammation resolution is an active cellular process. The last two decades have seen a revolution in these prevailing dogmas, with a significant contribution made by the authors. Microglia and infiltrating monocyte-derived macrophages are now known to be functionally distinct and of separate origin. Innate and adaptive immune cells are now known to have protective/healing properties in the CNS, as long as their activity is regulated, and their recruitment is well controlled; their role is appreciated in maintenance of brain plasticity in health, aging, and chronic neurodevelopmental and neurodegenerative diseases. Moreover, it is now understood that the barriers of the brain are not uniform in their interactions with the circulating immune cells. The implications of these new findings to the basic understanding of CNS repair processes, brain aging, and a wide spectrum of CNS disorders, including acute injuries, Rett syndrome, Alzheimer's disease, and multiple sclerosis, will be discussed.

\section{Introduction}

The epithelial border of the brain orchestrates trafficking of inflammation-resolving leukocytes to the CNS: implications to neurodegenerative diseases and aging

The prevailing notion that immune cells are unequivocally detrimental to the CNS was mainly a reflection of the anatomy of the brain, a tissue surrounded by barriers, and of the local neuroinflammation seen under almost all pathological conditions, including sterile injuries, chronic neurodegenerative diseases, neurodevelopmental diseases, and even depression. More than a decade ago, this view was revisited, and it was proposed that it is unlikely that such an essential tissue would be unable to harness

\footnotetext{
Received July 30, 2013; revised Aug. 26, 2013; accepted Aug. 28, 2013. Author contributions: M.S., J.K., S.R., and A.P. wrote the paper.

M.S. holds the Maurice and Ilse Katz Professorial Chair in Neuroimmunology. This work was supported by the European Research Council-Advanced Grant given to M.S. This work was primarily supported by the National Institute of Neurological Disorders and Stroke, National Institutes of Health Grant NS081026 to J.K. and the Rett Syndrome Research Trust. S.R. was supported by the Fonds de la Recherche du Québec-Santé, Canadian Institutes in Health Research, and the Multiple Sclerosis Scientific Research Foundation of Canada. A.P. is a senior research scholar from the Fonds de la Recherche en Santé du Québec whose research is supported by the Canadian Institutes in Health Research, Multiple Sclerosis Society of Canada, and the Multiple Sclerosis Scientific Research Foundation of Canada. J.K. thanks Nikki Watson for helping with the manuscript and laboratory members for their invaluable comments and hard work.

The authors declare no competing financial interests.

Correspondence should be addressed to Dr. Michal Schwartz, Department of Neurobiology, Weizmann Institute of Science, Rehovot 76100, Israel. E-mail: Michal.schwartz@weizmann.ac.il.

DOI:10.1523/JNEUROSCI.3241-13.2013

Copyright $\odot 2013$ the authors $\quad 0270-6474 / 13 / 3317587-10 \$ 15.00 / 0$
}

the body's key system of maintenance and repair, the immune system (Schwartz et al., 1999; Schwartz and Cohen, 2000; Schwartz and Shechter, 2010a). Using models of acute axonal injury, such as injury to the optic nerve or spinal cord, key observations were made by demonstrating that monocyte-derived macrophages and $\mathrm{CD} 4{ }^{+} \mathrm{T}$ cells recognizing brain antigens (autoimmune $\mathrm{T}$ cells) have an essential supportive role in recovery from injurious conditions (Rapalino et al., 1998; Moalem et al., 1999; Hauben et al., 2001; Yoles et al., 2001) as well as chronic neurodegenerative diseases (Frenkel et al., 2003; Serpe et al., 2003; Beers et al., 2008; Reynolds et al., 2010). Nevertheless, following these initial observations, some puzzling questions remained unresolved: (1) What is the nature of the autoimmune T cells (effector, regulatory, or both) needed for CNS repair, and what are the relationships between their beneficial effect and that of innate immune cells, including the blood-borne macrophages and activated resident microglia? (2) Why are blood-borne macrophages needed for repair if the CNS is populated by resident microglia? Do the macrophages account for microglial turnover? Are microglia and macrophages redundant cells, or do they have distinct activities? (3) How can the benefit of CNS-specific T cells be reconciled with the general perception of autoimmune cells as causing autoimmune disease? (4) How do the immune cells benefit the CNS if their entry requires breaching of the blood-brain barrier (BBB)? (5) If indeed circulating immune cells are needed for recovery, why is their recruitment limited after injury? (6) If immune cells are needed for repair, as an extreme case of restor- 
ing homeostasis, do these cells also have a role in normal brain plasticity as well? (7) Finally, if immune cells have a role in lifelong brain plasticity, what is their involvement in delaying aging of the brain, onset of chronic neurodegenerative disease, or development of congenital neurodevelopmental disease?

Monocyte-derived macrophages have an essential role as inflammation-resolving cells in recovery from acute CNS injury. Macrophage heterogeneity (Auffray et al., 2009) in the CNS was not appreciated until recently with respect to function (Shechter et al., 2009) and origin (Ginhoux et al., 2010), as activated macrophages and resident microglia are indistinguishable by histological criteria; thus, these two cell populations, when activated, were considered to be redundant and similarly detrimental (Gensel et al., 2009). However, in 1998, injection of ex vivo "alternatively activated" blood macrophages was shown to promote recovery from experimentally induced spinal cord injury ( $\mathrm{Ra}-$ palino et al., 1998). These pioneering observations were the first indications that blood-borne macrophages are potentially beneficial for CNS repair. Using chimeric mice, in which monocytes, but not the microglia, express a green fluorescent protein, GFP $\left(\mathrm{CX}_{3} \mathrm{CR} 1^{\text {gfp }}>\right.$ wild-type chimeras), it became possible to distinguish between resident-activated microglia and infiltrating monocyte-derived macrophages, at the site of spinal cord injury (Rolls et al., 2008; Shechter et al., 2009). Importantly, in the absence of injury, blood-derived macrophages are excluded from the healthy host brain (as long as the heads of the mice are shielded during the irradiation process that is required to ablate the host bone marrow to enable engraftment) (Shechter et al., 2009). After spinal cord injury, blood-derived $\mathrm{GFP}^{+}$myeloid cells were found at the lesion site; yet, the majority of these recruited cells arrived with a delay relative to the initial injuryassociated breach of the BBB. Conditional ablation of the recruited blood-derived macrophages, using an ablation system based on expression of the diphtheria toxin receptor under control of the CD11c (a macrophage-specific marker) promoter (Jung et al., 2002), worsened the functional motor score of the injured animals, extended the lesion size, and led to an overall enhanced inflammatory response manifested by the local activated microglia (Shechter et al., 2009). Thus, it was found that the blood-derived macrophages are recruited to the injury site after insult and facilitate the resolution of the local immune response by displaying an anti-inflammatory activity required for the regulation of the activated microglia (Shechter et al., 2009). Analysis of the type and activity of the monocytederived macrophages at the lesion site as a function of time revealed that, under injurious conditions, both monocyte-derived macrophages expressing proinflammatory activity (M1-like) and monocyte-derived macrophages inducing anti-inflammatory effects (M2-like) are present, although the former population appears earlier and its presence is transient (Shechter et al., 2013b). It was further found that the activity of M2-like blood-derived macrophages is dependent on the expression of IL-10, the classical antiinflammatory cytokine known to be associated with alternatively activated (M2) macrophages (Shechter et al., 2009). Ablation of the blood-derived macrophages followed by their replacement with macrophages that are defective in IL-10 expression results in impaired overall recovery (Shechter et al., 2009). Conversely, boosting normal monocyte recruitment results in improved recovery (Shechter et al., 2009).

Within the time frame of the resolution of the local innate inflammatory response, the resident microglia fail to acquire an M2-like phenotype. It was also found that acquisition of this resolving (M2) phenotype is dependent on their spatial colocalization with the extracellular matrix proteins, chondroitin sulfate proteoglycan (Rolls et al., 2008, 2009), known to be inhibitory for axonal growth (Silver and Miller, 2004; Fawcett, 2009). Intriguingly, the monocyte-derived macrophages, which acquire their anti-inflammatory activity in part through their interaction with chondroitin sulfate proteoglycan, also express enzymatic activity that allows them to dissociate the matrix through which regrowing axons need to extend (Shechter et al., 2011). Collectively, these results suggested that recruitment of monocytes is required for resolution of the inflammatory response and of the scar. Both inflammation and the scar are essential phases of healing that nevertheless become destructive if not resolved in a timely manner (Shechter and Schwartz, 2013a, b). Independent studies have shown that macrophages support axonal regeneration (Yin et al., 2006) and that well-controlled innate immunity also supports CNS cell renewal under pathological conditions (Martino et al., 2011; Kokaia et al., 2012).

$T$ cells at the borders of the brain coordinate communication of the CNS with the periphery. The findings that the monocytederived macrophages recruited to the CNS are vital and beneficial cells, and display a role that is nonredundant with that of the microglia in resolving the inflammatory response (Shechter et al., 2009), raised a key question regarding how such myeloid cells are recruited to the CNS. A few years ago, it was demonstrated that active or passive vaccination with CNS antigens, but not with a non-self-protein, enhances recovery after axonal injury (Moalem et al., 1999; Hauben et al., 2001). Subsequently, it was demonstrated that boosting levels of CNS-specific circulating $\mathrm{T}$ cells facilitates the accumulation of M2-like monocyte-derived macrophages at the site of the injury (Shechter et al., 2009). Yet, it remained unclear how the two phenomena are related. Recently, it was found that those monocyte-derived macrophages, which are recruited to the lesion site and locally differentiate to become resolving macrophages (M2-like), enter through a designated barrier, the choroid plexus (CP) within the blood-CSF barrier, rather than through breached BBB. The blood-CSF barrier is a unique barrier in the CNS as it is composed of epithelial cell tight junctions and fenestrated endothelial cells, rather than endothelial tight junctions. Thus, it was shown that the blood-CSF barrier is not a "true" fixed barrier that blocks immune cell entry, but rather, a selective and educative gate that enables selective cell access, depending on the needs of the CNS (Shechter et al., 2013a; Kunis et al., 2013). Recent examination of the cellular composition of the CP stroma revealed that it is constitutively populated by distinct populations of CD4 ${ }^{+} \mathrm{T}$ cells, which differ from those in the blood circulation. High-throughput sequencing analysis of the $\mathrm{T}$-cell receptor repertoire revealed that these $\mathrm{CD} 4^{+} \mathrm{T}$ cells express T-cell receptors specific for CNS antigens and that their memory phenotype is of an effector-memory type, in contrast to the CSF, which is populated by central-memory T cells (Baruch et al., 2013). Approximately $15 \%$ of these $\mathrm{CD}^{+}{ }^{+}$cells in the naive $\mathrm{CP}$ were found to be IFN- $\gamma$-producing Th1 cells, and their activity in this compartment was found to be crucial for the activation of the $\mathrm{CP}$ as a gate for leukocyte trafficking to the CNS, by inducing its expression of trafficking molecules (Kunis et al., 2013). These and additional results suggest that CNS-specific T cells residing in the CP serve as "gatekeepers," mediating their local and remote functions from within the CNS territory but outside the parenchyma (Baruch and Schwartz, 2013).

The discovery of CNS-specific T cells at the CP was consistent with the discovery that CNS-specific T cells are involved in the maintenance of the functional plasticity of the healthy brain, including hippocampal-dependent cognitive abilities and neurogenesis (Kipnis et al., 2004; Ziv et al., 2006; Ziv and Schwartz, 
2008; Wolf et al., 2009). Mice deficient in T cells or CNS-specific $\mathrm{T}$ cells were found to exhibit reduced spatial learning and memory capabilities (Kipnis et al., 2004; Ziv et al., 2006). Moreover, sudden imposition of immune deficiency in young mice causes spatial-memory impairment, similar to age-associated memory loss, which can be reversed by immune reconstitution (RonHarel et al., 2008). Importantly, these studies, which suggested that regulated immune cell activity is needed to maintain brain plasticity, do not contradict results suggesting that severe inflammation impairs neurogenesis. Rather, these results suggest that immune cells regulate the homeostasis of the healthy parenchyma even from afar (Derecki et al., 2010; Schwartz and Shechter, 2010b; Ron-Harel et al., 2011), yet the type of immune activation critically determines its outcome (Monje et al., 2003; Wurmser et al., 2004; Ekdahl et al., 2009; Rolls et al., 2009; Derecki et al., 2010; Lindvall and Kokaia, 2010).

Based on the anatomical location and physiological functions of the $\mathrm{CP}$, we proposed that this unique neuro-immunological interface is the site from which "protective immunity" can affect brain function from afar and that the CP-resident CNS-specific $\mathrm{CD} 4{ }^{+}$cells perform their regulatory function in response to deviation in either the periphery or within the CNS. Thus, effector CNS-specific $\mathrm{CD}^{+}{ }^{+} \mathrm{T}$ cells, via IFN $\gamma$, facilitate immune cell recruitment through the brain's CP (Kunis et al., 2013) and support brain plasticity through their remote activity, via tightly controlled levels of IL-4 (Derecki et al., 2010; Baruch et al., 2013); such interactions, reflecting the ongoing cross talk between immune cells and the CP, dynamically shape the brain and adjust to the needs of the CNS for maintenance, protection, or repair (Baruch and Schwartz, 2013).

The fact that immune deviation in circulating immunity affects the local effector cytokine milieu in the CP stroma, which in turn affects $\mathrm{CP}$ function, led to the discovery that the aged $\mathrm{CP}$ is characterized by overwhelming levels of IL-4 (Baruch et al., 2013), leading to an overall milieu that is reminiscent of local Th2 inflammation (Shearer, 1997; Rink et al., 1998). Chronic elevation of IL-4 or acute high IL-4 levels are linked to epithelial Th2mediated inflammation and were most extensively studied in cases of asthma, chronic obstructive pulmonary disease, and cystic fibrosis (Cockcroft and Davis, 2006). In such situations, the effects of IL-4 on epithelial tissues are destructive, inducing the remodeling of the epithelium and contributing to a progressive decline in function (Maarsingh, 2008). Similar age-related overwhelming local levels of IL-4 were found to disrupt the CP epithelial tight junctions, associated with a decrease in barrier properties (Baruch et al., 2013), and are coupled with local elevation of arginase-1, a change that is strongly associated with Th2inflamed epithelial tissues (Maarsingh, 2008). Importantly, the local Th2-inflammation of the aged CP was found to trigger epithelial cells to produce the chemokine, CCL11 (Baruch et al., 2013), whose elevation in the plasma and CSF was recently linked to impaired cognitive function and reduced hippocampal neurogenesis (Villeda et al., 2011; Villeda and Wyss-Coray, 2013). As CCL11 is the ligand for the CCR3 receptor, which is expressed on myeloid cells (He et al., 1997), it is possible that CCL11 acts on the CNS-resident microglia or meningeal macrophages, shifting their phenotype to a proinflammatory state, and thereby indirectly affecting brain function. Thus, it is possible that CCL11 derived from the aged $\mathrm{CP}$ affects brain plasticity by either inhibiting the balanced levels of IL-4 shown to be essential for brain plasticity (Derecki et al., 2010) or directly inhibiting neurogenesis, as was demonstrated in vitro (Butovsky et al., 2006; Villeda et al., 2011). Regardless of the mechanism of action of CCL11, it is likely that the local Th2 inflammation in the aged CP is part of an overall age-related immunological dysregulation in this compartment, which involves the secretion of additional factors to the CSF that might interfere with brain function.

The immune network as the missing link in chronic neurodegenerative diseases. Based on these results, it is clear that the brain's epithelial barrier, the $\mathrm{CP}$, serves as an interface, through which the CNS parenchyma delivers signals indicating needs, and the circulation provides signals recruiting help. Innate immune cells in the parenchyma, under physiological conditions, are sentinels that sense mild deviations from homeostasis, and contain them. Under severe injuries or chronic disease conditions, these resident cells are often inefficient, unresponsive, or defective and must receive assistance or be replaced, as will be discussed below.

Accordingly, the immune cells in the periphery display distinct and complementary roles from those of the immune cells within the brain parenchyma. The parenchyma requires the recruitment of inflammation-resolving cells to the diseased or injured tissue (Shechter et al., 2009). Yet, results suggest that for this to happen, the CP must be activated. The CP, however, may not be sufficiently activated because of either a deficiency in effector $\mathrm{T}$ cells, overwhelming levels of circulating suppressor immune cells, such as $\mathrm{FOXP}^{+}{ }^{+}$regulatory $\mathrm{T}$ cells, which are elevated in aging and in chronic neurodegenerative conditions (for review, see He and Balling, 2013), or lack of "danger" signals from the parenchyma. According to this view, the state of the immune cells in the circulation should provide an indication of how to modify the circulating immunity as a means of modulating the $\mathrm{CP}$ to ensure its proper activation, and optimal function as a gate for recruiting immune cells that will locally contribute to immune resolution, restoration of homeostasis, or tissue restoration. Together, our current understanding suggests a novel target for therapy of neurodegenerative diseases modulating the CP. Although the target is common to all neurodegenerative conditions, the specific approach will differ depending on the nature of the CP dysfunction, and whether such dysfunction is an outcome of the circulating immune milieu, or the CSF signaling.

\section{Microglia and monocyte-derived macrophages in neurodevelopmental pathology}

Just as birth and death of organisms occur on a day-to-day basis, these processes also occur on a microscopic scale in all cells of all living organisms. This balance between birth and death at the cellular level must be exquisitely regulated to maintain normal function and avoid pathology. Failure to adequately remove dead and damaged cells leads to a buildup of cellular debris, which can be potentially harmful to neighboring cells and detrimental to generative processes, thus leading to inadequate development in early life, or early onset of degenerative disorders and premature "aging" (Elliott and Ravichandran, 2010; Gregory and Pound, 2011). This is particularly important in the brain, where the tissue is intensely metabolic, encapsulated within the confines of the skull, which essentially serves as an exoskeleton, and separated from the organism's circulatory system by the BBB (Tremblay et al., 2011; Schafer et al., 2012; Aguzzi et al., 2013). We propose that phagocytosis, the mechanism for clearance of both self and foreign cellular material, is critical to normal brain development and function, and that imbalance in this process of clearance and regeneration may contribute to a number of developmental abnormalities: Rett syndrome, autism spectrum disorders (Derecki et al., 2012, 2013) and neurodegenerative disorders (Alzheimer's disease $[\mathrm{AD}]$ and Parkinson's disease) (Landreth and ReedGeaghan, 2009; Lee and Landreth, 2010). 
Phagocytosis has long been understood in the context of its innate immune function, whereby professional phagocytes (microglia in the CNS) engulf and degrade foreign materials associated with pathogen invasion or created as a result of injury. However, a larger picture is beginning to emerge, revealing important roles for microglia that go beyond this pathogenic response and include homeostatic maintenance and support roles for neurons (Tremblay et al., 2011; Schafer et al., 2012; Aguzzi et al., 2013). Indeed, mice in which microglia (and all other macrophages) have been genetically removed, postnatal brain development is severely perturbed, strongly supporting a role for microglia in homeostatic brain development and function (Erblich et al., 2011). Similarly, our understanding of phagocytosis is expanding to include cells not traditionally associated with engulfment of waste materials (nonprofessional phagocytes), the astrocytes and progenitor cells, in these maintenance and support roles (Wu et al., 2009; Lu et al., 2011).

Recent work using mice deficient in methyl-CpG binding protein 2 (Mecp2-null mice), a gene found to be mutated in the autism spectrum disorder, Rett syndrome (Zoghbi, 2002, 2005), revealed an important role for phagocytosis by microglia in this model (Derecki et al., 2012). These mice show much of the symptomology seen in Rett patients: growth retardation, breathing irregularities and apneas, and shortened lifespan (Chen et al., 2001; Guy et al., 2001). Bone marrow transplantation with wildtype donor marrow resulted in significant engraftment of microglia-like cells into the brains of these Mecp2-null mice and essentially arrested disease pathology (Derecki et al., 2012). We subsequently determined that microglia from the Mecp2-null mice exhibit profoundly impaired phagocytic ability compared with wild-type microglia, suggesting that insufficient clearance of debris from the brains of these animals may contribute to the pathology. In addition, specific expression of wild-type Mecp2 in myeloid cells of these null animals $\left(\operatorname{Lysm}^{\text {cre }} M e c p 2^{\text {lox-stop/y }}\right)$ arrested symptomology, but recovery was prevented if phagocytic activity was impaired pharmacologically by blocking phosphatidylserine recognition using annexin $\mathrm{V}$. These data provide promising new approaches for the treatment of Rett syndrome and other neurodevelopmental and neurodegenerative disorders where the buildup of debris may contribute to pathology. Such diseases may include Alzheimer's, Parkinson's, and Huntington's diseases, and potentially other psychiatric disorders whose etiology has previously been considered exclusively neurogenic in nature (Yong and Rivest, 2009). Moreover, Nasu-Hakola disease, a neurodegenerative disorder, has also been directly linked to dysfunction of microglial phagocytosis through mutations of triggering receptor expressed on myeloid cells-2 (TREM2), a protein which is critical for microglial phagocytosis of apoptotic neurons and is only expressed on microglia in the brain (Takahashi et al., 2005; Thrash et al., 2009).

As to the role of nonprofessional phagocytes in brain function, we have shown that double-cortin-positive neuronal progenitor cells play a significant role in adult neurogenesis through clearance of accumulating apoptotic material in the neurogenic niches (Lu et al., 2011). Two areas of the brain remain actively neurogenic in adulthood: the subventricular zone of the lateral ventricles and the subgranular zone of the hippocampal dentate gyrus. Within these niches, many thousands of double-cortin-positive neuronal progenitor cells are generated each day, some destined to become new neurons, others to become supporting glial cells (astrocytes and oligodendrocytes), but many simply die off during the process of network pruning and refinement. Because this is an area of active cell (re)cycling, we wished to identify the cell type(s) involved in phagocytosis in these areas. Our initial focus was on astrocytes and astrocytic stem cells (glial fibrillary acidic protein-expressing cells) because glia universally play major phagocytic roles. To our surprise, however, the fluorescently labeled phosphatidylserine-containing liposomes used to track phagocytosis appeared predominantly in double-cortin-positive neuronal precursor cells in both these neurogenic niches. This observation led us to speculate that inhibition of phagocytosis might negatively impact progenitor differentiation and neuronal development in vivo. Using annexin $\mathrm{V}$, we inhibited apoptotic cell clearance, which led to accumulation of apoptotic cell debris, and a marked reduction in neuronal differentiation and survival, indeed suggesting that an inability to clear cellular debris in these brain areas impairs neurogenesis (Lu et al., 2011).

Together, these studies strongly support the notion that failure on the part of brain phagocytes, whether professional or nonprofessional, to clear the extensive accumulation of debris associated with normal neurogenesis, results in impaired neuronal differentiation, development, and survival and may contribute to the pathology of diseases formerly considered purely neurological in nature, including Rett syndrome, Alzheimer's disease, and Fragile X. Therefore, it is tempting to speculate that restoring phagocytic activity in those conditions where it is lost (Rett syndrome), or augmenting it in those where degeneration may be accelerated (Alzheimer's disease), may lead to profound improvement in these conditions. Although pharmacological agents have been identified that inhibit or prevent phagocytosis, agents that selectively stimulate phagocytic activity remain to be identified but could provide useful new treatment approaches.

\section{Microglia and monocyte-derived macrophages in chronic neurodegenerative diseases}

In cases of infections, traumas, and pathological conditions, the CNS comes into contact with small protein sequences forming patterns that regulate innate immunity, found in large numbers of microorganisms. Such patterns (named PAMPs for pathogenassociated molecular patterns and DAMPS for damage-associated molecular patterns) include proteins from bacterial membranes, such as peptidoglycans, intracellular proteins, such as heat-shock proteins, and small nonprotein molecules, such as ATP and urea, and nucleic acid patterns, such as nonmethylated CpGcontaining DNA, dsRNA, and ssRNA (Kumar et al., 2011). These are recognized by pattern recognition receptors (PRRs) of which three major families exist: Toll-like receptors (TLRs), Nod-like receptors (NLRs), and RIG1-like receptors (RLRs). The role of these receptors in the CNS has been mostly studied in microglia, but astrocytes, oligodendrocytes, endothelial cells, and even neurons and neural stem cells also express functional levels of some of these receptors (Rolls et al., 2007; Okun et al., 2010; Hanamsagar et al., 2012). The engagement of such receptors results in the induction of specific pathways and the release of specific cytokines that play a role in resolving injury. There are 11 TLR family members in humans and 13 in mice. A role for TLR1-9 has been described in the CNS; and although mostly active in microglia, TLRs are also found in neurons, astrocytes, and endothelial cells. TLRs can act alone or heterodimerize to create specific responses to a given stimuli. All TLRs, except TLR3, signal through the adaptive protein, Myd88, which leads to the induction of NF- $\kappa \mathrm{B}$ and the release of cytokines, such as IL- $1 \beta$, TNF- $\alpha$, and IL-12. Conversely, TLR3 cannot activate Myd88, but signals through a TRIF-dependent pathway, leading to the induction of IRF3 and the production of other cytokines, such as IFN $\beta$. TLR4 can also signal through TRIF with the help of the adaptor protein, TRAM. 
Both Myd88 and TRIF-dependent signaling pathways can engage mitogen-associated protein kinase (MAPK) pathways, including ERK1/2, p38, and JNK, which lead to the stimulation of cell growth and the induction of inflammatory cytokine production (Brown et al., 2011).

Microglia: a powerhouse of the innate immune system in the CNS. Considered tissue-resident macrophages, much like Kupffer cells in the liver or histiocytes in connective tissues, microglia are the only cells in the CNS of hematopoietic origin (Soulet and Rivest, 2008b). Fate-mapping analysis has demonstrated that hematopoietic precursors from the yolk sack populate the CNS before the eighth embryonic day in mice (Ginhoux et al., 2010). Once present, microglia are capable of self-renewal and do not require replenishment by circulating monocytic precursors (Ajami et al., 2007). They are thus distinct from the monocyte lineage of cells and other tissue-specific macrophages, such as Kuppfer cells, in the liver for which the maintenance is dependent upon the recruitment of bone marrow-derived cells from the circulation (Klein et al., 2007). In the CNS, initial reports suggested that the recruitment of bone marrow-derived cells was an active event in normal physiology (Simard and Rivest, 2004). After an intense debate on the subject (Soulet and Rivest, 2008a), a consensus appears to have been reached following new experimental evidence that bone marrow-derived cell recruitment is a marginal effect in normal physiology (Lampron et al., 2012), but important in pathological conditions affecting the integrity of the CNS, such as stroke (Schilling et al., 2009), multiple sclerosis (Floris et al., 2004), amyotrophic lateral sclerosis (Vaknin et al., 2011), and others. This recruitment can be beneficial or harmful, depending on the condition studied (Shechter and Schwartz, 2013b).

In their native state, microglia are highly ramified cells with a small cellular body. Their extended processes allow microglia to rapidly sense the presence of tissue damages or signs of infections through PRRs. Microglia are highly plastic cells; they respond rapidly to the danger signals released by injured cells and secrete appropriate cytokines to both clear debris and to attract other microglial cells (Soulet and Rivest, 2008b). They are specialized cells that respond to specific stimuli in a much more specific and ordered manner than was previously thought. To simplify the concept of microglial response, a dichotomy in the activation states of microglia was suggested. Based on the Th1/Th2 and $\mathrm{M} 1 / \mathrm{M} 1$ activation states of T cells and macrophages, respectively, two basic states were suggested for microglia, mostly dependent upon the nature of the stimulus. In the M1 activation state, also known as the classically activated or proinflammatory state and modeled in vitro by LPS stimulation, microglia show that high levels of Ly6C expression secrete proinflammatory cytokines, such as IL- $1 \beta$ and TNF- $\alpha$, and have a high potential for phagocytosis and proteolysis (Martinez et al., 2008). Through the release of iNOS and ROS, M1 monocytes are specialized for the clearance of bacterial infections. In the M2 state, also called the alternatively activated or tissue repair state and induced in vitro by IL-4 or IL-10, microglia showing lower levels of Ly6C expression are geared toward tissue repair through the production of VEGF, chemokines, and extracellular matrix proteins. Whereas the M1/M2 paradigm facilitates a broad view of the role of these cells in a given situation, the situation seems far more complex during chronic brain diseases, such as AD.

Microglia and blood-born monocytes in $A D . \mathrm{AD}$ is caused mainly by the production of amyloid- $\beta(\mathrm{A} \beta)$ in the CNS. The innate immune system plays a role in the development of the pathology, as chronic exposure of microglia to $A \beta$ leads to un- controlled inflammation, and the release of toxic free radicals and reactive oxygen species, as originally described in postmortem studies (Uchihara et al., 1997; Cagnin et al., 2001). Furthermore, large-scale genome-wide association studies of thousands of $\mathrm{AD}$ subjects have shown that, among the six genetic polymorphisms most tightly linked to the development of late onset $\mathrm{AD}$, four play a dominant role in immunological processes (Moraes et al., 2012). In the serum, CSF, and the cortex of affected patients, higher levels of IL- $1 \beta$, IL- 6 , TNF $\alpha$, IL- 8 , and TGF $\beta$ have all been reported (for in-depth reviews, see Rubio-Perez and MorillasRuiz, 2012; see also Akiyama et al., 2000; Town et al., 2008). Similarly, both TLR2 and TLR4 are overexpressed in peripheral blood mononuclear cells from patients with AD (Zhang et al., 2012). It also appears that the main monocytic chemoattractant, CCR2, and its ligand, CCL2, are involved in the progression of AD (Conductier et al., 2010; Naert and Rivest, 2011; Westin et al., 2012). Furthermore, although no genetic association at the TLR4 locus was found in genome-wide association studies for AD (Moraes et al., 2012), polymorphisms in the TLR4 gene were shown to increase the incidence of late onset $\mathrm{AD}$ in populations from Italy (Minoretti et al., 2006; Balistreri et al., 2008) and China (Wang et al., 2011; Chen et al., 2012; Yu et al., 2012). The reported data on humans suggest that, in essence, $\mathrm{AD}$ is first and foremost an immunological disease.

It is still highly debated whether the activation of the innate immune system is a cause or a consequence of the development of $\mathrm{AD}$. In vitro studies showed that fibrillar $\mathrm{A} \beta$ acts directly on microglia, activating TLR4 and TLR2 and the release of TNF $\alpha$, which lead to neuronal death, as demonstrated in microglial cell lines and microglia-neuron coculture (Udan et al., 2008; ReedGeaghan et al., 2009; Stewart et al., 2010). On the other hand, in vivo studies in mouse models present another picture. Knockouts or genetic inactivation of TLR4 (Tahara et al., 2006; Song et al., 2011), TLR2 (Richard et al., 2008), Myd88 (Michaud et al., 2012), or TNF $\alpha$ receptors (Montgomery et al., 2011) in mouse models of $\mathrm{AD}$ all aggravate the symptoms of the disease, affecting both cognitive function and amyloid deposition. These studies have led to a better understanding of inflammatory processes in AD. Multiple factors (genetic predisposition, ineffective clearance, previous injuries) induce accumulation of $A \beta$ in the CNS into toxic oligomers and plaques. These are detected by microglia as DAMPs, activating a TLR2/TLR4 response. Although microglia can effectively clear A $\beta$ in vitro (Reed-Geaghan et al., 2009), these cells are not sufficient to resolve the injury in vivo, as $\mathrm{A} \beta$ production surpasses the microglia's capacity for clearance.

The innate immune system, however, does possess a capacity for the clearance of $\mathrm{A} \beta$ and can play a beneficial role in $\mathrm{AD}$. This would explain the detrimental effects of completely knocking out the innate immune response, whereas its selective inhibition can prove to be an efficient therapeutic strategy. This was highlighted by the failure of NSAIDs to control AD in large-scale clinical trials (Imbimbo, 2009). Initial reports indicated that patients prescribed extended courses of NSAIDs had lower incidence of AD (McGeer et al., 1996). However, it appeared that the subjects on NSAIDs actually had a lower incidence of AD because of their overly active innate immune system, which helped prevent the development of AD. Immune suppression by NSAIDs did not contribute to $\mathrm{AD}$ mitigation.

As such, a tightly regulated stimulation of innate immune processes rather than its complete inhibition is another way of designing new treatment options for AD. This can be achieved using novel TLR ligands that can stimulate the clearance of $A \beta$ without inducing overt inflammatory processes. Recently the 
beneficial effects of monophosphoryl lipid A was demonstrated in mouse models of AD (Michaud et al., 2013). Monophosphoryl lipid A, a detoxified TLR4 ligand, induced strong phagocytic activity in microglia, similar to LPS, while inducing almost undetectable production of inflammatory cytokines or ROS. In $\mathrm{AD}$ mouse models, chronic treatment with monophosphoryl lipid A reduced $\mathrm{A} \beta$ production by up to $80 \%$ in some cases and normalized their cognitive behavior. This paves the way for the development of safe immunomodulatory therapies in $\mathrm{AD}$ as a monotherapy but also as a complementary treatment to other $\mathrm{A} \beta$-lowering strategies, such as vaccination.

Although most of the work in AD has focused on neurodegeneration and inflammatory processes, accumulating evidence shows that a dysregulation of the vasculature is just as important in the development of AD (Zlokovic, 2011). Most studies on the implications of innate immunity in $\mathrm{AD}$ have focused on the role of microglia. However, novel exciting research shows that the rest of the neurovascular unit is a prime candidate for the creation of new therapeutic strategies for AD. Pioneering work from the team of Zlokovic has shown that LRP-1, a specific transporter at the $\mathrm{BBB}$, is critical for the clearance of $\mathrm{A} \beta$ from the CNS into the circulation (Deane et al., 2004). In further studies, the authors found that LRP-1 is upregulated upon LPS stimulation, therefore presumably enhancing pericyte and endothelial cell capacity to internalize $\mathrm{A} \beta$ (Deane et al., 2008). Moreover, adenosine triphosphate ATP-binding cassette $(\mathrm{ABC})$ transporters $\mathrm{ABCB} 1$ and $A B C G 2$ were shown to be involved in the elimination of $A \beta$ from the CNS (Cirrito et al., 2005; Xiong et al., 2009; van Assema et al., 2012). These results have suggested the hypothesis that clearing $\mathrm{A} \beta$ in the circulation could shift its equilibrium, thereby pulling the $A \beta$ from the CNS into the circulation through these transporters. This so-called "sink hypothesis" supports targeting the periphery to have positive effects on the CNS. One such compound that could help clear $A \beta$ is macrophage-colony stimulating factor (M-CSF), the main growth factor for cells of the monocytic lineage (Hume and MacDonald, 2012). Weekly injection of M-CSF to transgenic mice that spontaneously develop $\mathrm{AD}$ before the appearance of learning and memory deficits prevented cognitive loss. The treatment also restored the population of M1 monocytes in the circulation and greatly decreased $\mathrm{A} \beta$ levels. In addition, M-CSF treatment resulted in the stabilization of the cognitive decline in transgenic mice that already exhibited $\mathrm{A} \beta$ pathology (Boissonneault et al., 2009). In vitro, exposure of mouse microglia to M-CSF enables the acidification of their lysosomes and, subsequently, the degradation of internalized $\mathrm{A} \beta$ (Majumdar et al., 2007). In this regard, low levels of M-CSF were recently measured in patients with presymptomatic $\mathrm{AD}$ or mild cognitive impairment, which together with low levels of other hematopoietic cytokines predicted the rapid evolution of the disease toward a diagnosis of dementia 2-6 years later (Ray et al., 2007). This is one of the ways the hematopoietic system can be used to treat $\mathrm{AD}$ (Lampron et al., 2011).

Reverse paradigm. The CNS can also shape the immune response In the previous sections, we emphasized on the capacity of the immune system to shape the properties of the CNS, during aging and in specific neurological disorders. However, it is now becoming evident that the reverse is true: molecules produced by the CNS, whether specific or not for the CNS environment, have the capacity to modulate the properties and the function of the immune system, of the BBB and of the neurovascular unit. We now intend to focus the discussion around the influence of two classical brain morphogens in the regulation of immune functions within the CNS.

\section{Brain morphogens shape immune responses within the CNS}

The $\mathrm{BBB}$ is a functional CNS structure composed of specialized endothelial cells (ECs), which are under the critical influence of perivascular astrocytes. The BBB is known to regulate CNS function though a number of physiological processes, among which is controlling the entry of blood-borne molecules and circulating immune cells that are crucial in regulating immune activation during homeostasis and disease.

The specialized ECs forming the BBB are held together by multiprotein complexes known as junctional proteins (Lippoldt et al., 2000; Wolburg and Lippoldt, 2002; Alvarez and Teale, 2007). Astrocytes, which are in close apposition to the cerebral vasculature, help maintain BBB integrity and immune quiescence through contact-dependent mechanisms and through the release of soluble factors (Arthur et al., 1987; Wosik et al., 2007; Alvarez et al., 2011). TGF- $\beta$, neurotrophins, FGFs, and retinoic acid have been identified as factors released by astrocytes that contribute to optimal BBB functioning (Fabry et al., 1995; Koyama et al., 2003; Reuss et al., 2003; Wall, 2003; Koyama et al., 2005; Mizee et al., 2013).

Recent proteomic experiments performed using primary cultures of human BBB-ECs have identified the expression of a number of receptors for molecules classically referred to as brain morphogens, including receptors for Netrins and for the Hedgehog pathway. These observations served as the basis for the hypothesis that brain morphogens have the capacity to regulate $\mathrm{BBB}$ function and therefore CNS homeostasis and immune quiescence.

Role of the Hedgehog pathway in regulating BBB function. Recent reports suggest that astrocytes express and secrete Sonic hedgehog (Shh) and that BBB-ECs bear Hh receptors and downstream transcription factors. In vitro and in vivo experiments showed that, whereas activation of the Hh pathway restricts BBB permeability, genetic and pharmacological neutralization of Shh or the $\mathrm{Hh}$ receptor, Smo, affects BBB formation and stability during fetal development and in adulthood. Specific neutralization of Smo in ECs led to a significant reduction in junctional protein expression and to the leakage of blood products (fibrinogen, immunoglobulins, and ApoB) into the CNS of these animals. Interestingly, Shh was also shown to promote immune quiescence of BBB-ECs by decreasing the expression of cell adhesion molecules, the production and secretion of proinflammatory chemokines, and the migration of immune cells. These critical immune-related events are dysregulated during neuroinflammation and lead to the formation of inflammatory lesions. Such recent developments in the field of BBB biology demonstrate that the Hh pathway provides a barrier-promoting effect and an endogenous anti-inflammatory mechanism within the CNS, and provide evidence for an unconventional role of brain morphogens in shaping immune responses within the CNS.

The role of the Netrin pathway in regulating CNS immune responses. Similar to the hedgehog morphogen family, the lamininlike molecule, netrins, mediate a wide range of functions throughout development and are best known for their role as attractive or repulsive guidance cues (Livesey, 1999; Kang et al., 2004; Adler et al., 2006). Netrins are known for their capacity to promote guidance for CNS commissural neurons and migration of oligodendrocyte progenitors. Their expression can also be induced by hedgehog morphogens. Recent data suggest that human and mouse BBB-ECs in vitro and in vivo express netrin- 1 and -4 and that netrin expression is regulated upon inflammatory activation. Netrins were also shown to promote BBB formation by inducing the expression of junctional complex molecules and 
their proper targeting to junctional membrane microdomains. Genetic neutralization of netrins induces numerous features of BBB breakdown, including disrupted TJ protein expression. During experimental autoimmune encephalomyelitis, a neuroinflammatory disease marked by BBB breakdown, netrin-1 therapy reduced serum protein leakage into the spinal cord and ameliorated disease severity.

Thus, accumulating evidence now suggests that classical brain morphogens have a significant role in promoting and maintaining BBB function and CNS immune quiescence both during development and during adulthood.

In conclusion, what does the future hold in harnessing immunity for prevention or treatment of acute, chronic, and developmental neurodegenerative conditions? As was briefly described above, over the last decade, research by four independent groups highlights the new era of neuroimmunology. It is no longer a field focused on pathologies in which the immune system is thought to attack the brain. Likewise, it is no longer a field in which the immune system should be indiscriminately excluded. It is a field in which the two systems not only interact but also have a mutual dependency. The brain, as has been known for decades, controls all functions of the body, including lymphoid organs. It is now clear that, reciprocally, the brain depends on immune cells for its maintenance and plasticity. Under disease conditions, such as neurodevelopmental or chronic age-related diseases, the resident immune cells are present in insufficient numbers or are insufficiently activated to cope with the threat, and circulating monocytes must be recruited. CNS barriers are no longer considered an impenetrable wall; the blood-CSF barrier serves as a functional interface and as a selective gate for immunosurveillance and immune cell entry upon need, the meninges as a site for immunedependent brain plasticity, and the $\mathrm{BBB}$ as a true barrier that ensures brain function without any disturbance. Translating this know-how would lead to improving brain plasticity and to the development of new approaches for the treatment of neurodevelopmental and neurodegenerative diseases, as well as mental disorders or brain aging and dementia.

\section{References}

Adler CE, Fetter RD, Bargmann CI (2006) UNC-6/Netrin induces neuronal asymmetry and defines the site of axon formation. Nat Neurosci 9:511518. CrossRef Medline

Aguzzi A, Barres BA, Bennett ML (2013) Microglia: scapegoat, saboteur, or something else? Science 339:156-161. CrossRef Medline

Ajami B, Bennett JL, Krieger C, Tetzlaff W, Rossi FM (2007) Local selfrenewal can sustain CNS microglia maintenance and function throughout adult life. Nat Neurosci 10:1538-1543. CrossRef Medline

Akiyama H, Barger S, Barnum S, Bradt B, Bauer J, Cole GM, Cooper NR, Eikelenboom P, Emmerling M, Fiebich BL, Finch CE, Frautschy S, Griffin WS, Hampel H, Hull M, Landreth G, Lue L, Mrak R, Mackenzie IR, McGeer PL, et al. (2000) Inflammation and Alzheimer's disease. Neurobiol Aging 21:383-421. CrossRef Medline

Alvarez JI, Teale JM (2007) Evidence for differential changes of junctional complex proteins in murine neurocysticercosis dependent upon CNS vasculature. Brain Res 1169:98-111. CrossRef Medline

Alvarez JI, Dodelet-Devillers A, Kebir H, Ifergan I, Fabre PJ, Terouz S, Sabbagh M, Wosik K, Bourbonnière L, Bernard M, van Horssen J, de Vries HE, Charron F, Prat A (2011) The Hedgehog pathway promotes bloodbrain barrier integrity and CNS immune quiescence. Science 334:17271731. CrossRef Medline

Arthur FE, Shivers RR, Bowman PD (1987) Astrocyte-mediated induction of tight junctions in brain capillary endothelium: an efficient in vitro model. Brain research 433:155-159. Medline

Auffray C, Sieweke MH, Geissmann F (2009) Blood monocytes: development, heterogeneity, and relationship with dendritic cells. Annu Rev Immunol 27:669-692. CrossRef Medline

Balistreri CR, Grimaldi MP, Chiappelli M, Licastro F, Castiglia L, Listì F,
Vasto S, Lio D, Caruso C, Candore G (2008) Association between the polymorphisms of TLR4 and CD14 genes and Alzheimer's disease. Curr Pharm Des 14:2672-2677. CrossRef Medline

Baruch K, Schwartz M (2013) CNS-specific T cells shape brain function via the choroid plexus. Brain Behav Immun. Advance online publication. Retrieved April 15, 2013. doi: 10.1016/j.bbi.2013.04.002.

Baruch K, Ron-Harel N, Gal H, Deczkowska A, Shifrut E, Ndifon W, MirlasNeisberg N, Cardon M, Vaknin I, Cahalon L, Berkutzki T, Mattson MP, Gomez-Pinilla F, Friedman N, Schwartz M (2013) CNS-specific immunity at the choroid plexus shifts toward destructive Th2 inflammation in brain aging. Proc Natl Acad Sci U S A 110:2264-2269. CrossRef Medline

Beers DR, Henkel JS, Zhao W, Wang J, Appel SH (2008) CD4+ T cells support glial neuroprotection, slow disease progression, and modify glial morphology in an animal model of inherited ALS. Proc Natl Acad Sci U S A 105:15558-15563. CrossRef Medline

Boissonneault V, Filali M, Lessard M, Relton J, Wong G, Rivest S (2009) Powerful beneficial effects of macrophage colony-stimulating factor on beta-amyloid deposition and cognitive impairment in Alzheimer's disease. Brain 132:1078-1092. CrossRef Medline

Brown J, Wang H, Hajishengallis GN, Martin M (2011) TLR-signaling networks: an integration of adaptor molecules, kinases, and cross-talk. J Dent Res 90:417-427. CrossRef Medline

Butovsky O, Ziv Y, Schwartz A, Landa G, Talpalar AE, Pluchino S, Martino G, Schwartz M (2006) Microglia activated by IL-4 or IFN- $\gamma$ differentially induce neurogenesis and oligodendrogenesis from adult stem/progenitor cells. Mol Cell Neurosci 31:149-160. CrossRef Medline

Cagnin A, Brooks DJ, Kennedy AM, Gunn RN, Myers R, Turkheimer FE, Jones T, Banati RB (2001) In-vivo measurement of activated microglia in dementia. Lancet 358:461-467. CrossRef Medline

Chen RZ, Akbarian S, Tudor M, Jaenisch R (2001) Deficiency of methylCpG binding protein-2 in CNS neurons results in a Rett-like phenotype in mice. Nat Genet 27:327-331. CrossRef Medline

Chen YC, Yip PK, Huang YL, Sun Y, Wen LL, Chu YM, Chen TF (2012) Sequence variants of toll like receptor 4 and late-onset Alzheimer's disease. PLoS One 7:e50771. CrossRef Medline

Cirrito JR, Deane R, Fagan AM, Spinner ML, Parsadanian M, Finn MB, Jiang H, Prior JL, Sagare A, Bales KR, Paul SM, Zlokovic BV, Piwnica-Worms D, Holtzman DM (2005) P-glycoprotein deficiency at the blood-brain barrier increases amyloid-beta deposition in an Alzheimer disease mouse model. J Clin Invest 115:3285-3290. CrossRef Medline

Cockcroft DW, Davis BE (2006) Mechanisms of airway hyperresponsiveness. J Allergy Clin Immunol 118:551-559; quiz 560-561. CrossRef Medline

Conductier G, Blondeau N, Guyon A, Nahon JL, Rovère C (2010) The role of monocyte chemoattractant protein MCP1/CCL2 in neuroinflammatory diseases. J Neuroimmunol 224:93-100. CrossRef Medline

Deane R, Wu Z, Sagare A, Davis J, Du Yan S, Hamm K, Xu F, Parisi M, LaRue B, Hu HW, Spijkers P, Guo H, Song X, Lenting PJ, Van Nostrand WE, Zlokovic BV (2004) LRP/amyloid beta-peptide interaction mediates differential brain efflux of Abeta isoforms. Neuron 43:333-344. CrossRef Medline

Deane R, Sagare A, Zlokovic BV (2008) The role of the cell surface LRP and soluble LRP in blood-brain barrier Abeta clearance in Alzheimer's disease. Curr Pharm Des 14:1601-1605. CrossRef Medline

Derecki NC, Cardani AN, Yang CH, Quinnies KM, Crihfield A, Lynch KR, Kipnis J (2010) Regulation of learning and memory by meningeal immunity: a key role for IL-4. J Exp Med 207:1067-1080. CrossRef Medline

Derecki NC, Cronk JC, Lu Z, Xu E, Abbott SB, Guyenet PG, Kipnis J (2012) Wild-type microglia arrest pathology in a mouse model of Rett syndrome. Nature 484:105-109. CrossRef Medline

Derecki NC, Cronk JC, Kipnis J (2013) The role of microglia in brain maintenance: implications for Rett syndrome. Trends Immunol 34:144-150. CrossRef Medline

Ekdahl CT, Kokaia Z, Lindvall O (2009) Brain inflammation and adult neurogenesis: the dual role of microglia. Neuroscience 158:1021-1029. CrossRef Medline

Elliott MR, Ravichandran KS (2010) Clearance of apoptotic cells: implications in health and disease. J Cell Biol 189:1059-1070. CrossRef Medline

Erblich B, Zhu L, Etgen AM, Dobrenis K, Pollard JW (2011) Absence of colony stimulation factor-1 receptor results in loss of microglia, disrupted brain development and olfactory deficits. PloS One 6:e26317. CrossRef Medline 
Fabry Z, Topham DJ, Fee D, Herlein J, Carlino JA, Hart MN, Sriram S (1995) TGF-beta 2 decreases migration of lymphocytes in vitro and homing of cells into the central nervous system in vivo. J Immunol 155:325-332. Medline

Fawcett J (2009) Molecular control of brain plasticity and repair. Prog Brain Res 175:501-509. CrossRef Medline

Floris S, Blezer EL, Schreibelt G, Döpp E, van der Pol SM, SchadeeEestermans IL, Nicolay K, Dijkstra CD, de Vries HE (2004) Blood-brain barrier permeability and monocyte infiltration in experimental allergic encephalomyelitis: a quantitative MRI study. Brain 127:616-627. CrossRef Medline

Frenkel D, Huang Z, Maron R, Koldzic DN, Hancock WW, Moskowitz MA, Weiner HL (2003) Nasal vaccination with myelin oligodendrocyte glycoprotein reduces stroke size by inducing IL-10-producing CD4+ T cells. J Immunol 171:6549-6555. Medline

Gensel JC, Nakamura S, Guan Z, van Rooijen N, Ankeny DP, Popovich PG (2009) Macrophages promote axon regeneration with concurrent neurotoxicity. J Neurosci 29:3956-3968. CrossRef Medline

Ginhoux F, Greter M, Leboeuf M, Nandi S, See P, Gokhan S, Mehler MF, Conway SJ, Ng LG, Stanley ER, Samokhvalov IM, Merad M (2010) Fate mapping analysis reveals that adult microglia derive from primitive macrophages. Science 330:841-845. CrossRef Medline

Gregory CD, Pound JD (2011) Cell death in the neighbourhood: direct microenvironmental effects of apoptosis in normal and neoplastic tissues. J Pathol 223:177-194. CrossRef Medline

Guy J, Hendrich B, Holmes M, Martin JE, Bird A (2001) A mouse Mecp2null mutation causes neurological symptoms that mimic Rett syndrome. Nat Genet 27:322-326. CrossRef Medline

Hanamsagar R, Hanke ML, Kielian T (2012) Toll-like receptor (TLR) and inflammasome actions in the central nervous system. Trends Immunol 33:333-342. CrossRef Medline

Hauben E, Agranov E, Gothilf A, Nevo U, Cohen A, Smirnov I, Steinman L, Schwartz M (2001) Posttraumatic therapeutic vaccination with modified myelin self-antigen prevents complete paralysis while avoiding autoimmune disease. J Clin Invest 108:591-599. CrossRef Medline

He F, Balling R (2013) The role of regulatory T cells in neurodegenerative diseases. Wiley Interdiscip Rev Syst Biol Med 5:153-180. CrossRef Medline

He J, Chen Y, Farzan M, Choe H, Ohagen A, Gartner S, Busciglio J, Yang X, Hofmann W, Newman W, Mackay CR, Sodroski J, Gabuzda D (1997) CCR3 and CCR5 are co-receptors for HIV-1 infection of microglia. Nature 385:645-649. CrossRef Medline

Hume DA, MacDonald KP (2012) Therapeutic applications of macrophage colony-stimulating factor-1 (CSF-1) and antagonists of CSF-1 receptor (CSF-1R) signaling. Blood 119:1810-1820. CrossRef Medline

Imbimbo BP (2009) Why did tarenflurbil fail in Alzheimer's disease? J Alzheimers Dis 17:757-760. CrossRef Medline

Jung S, Unutmaz D, Wong P, Sano G, De los Santos K, Sparwasser T, Wu S, Vuthoori S, Ko K, Zavala F, Pamer EG, Littman DR, Lang RA (2002) In vivo depletion of $\mathrm{CD} 11 \mathrm{c}(+)$ dendritic cells abrogates priming of CD8 $(+)$ $\mathrm{T}$ cells by exogenous cell-associated antigens. Immunity 17:211-220. CrossRef Medline

Kang JS, Yi MJ, Zhang W, Feinleib JL, Cole F, Krauss RS (2004) Netrins and neogenin promote myotube formation. J Cell Biol 167:493-504. CrossRef Medline

Kipnis J, Cohen H, Cardon M, Ziv Y, Schwartz M (2004) T cell deficiency leads to cognitive dysfunction: implications for therapeutic vaccination for schizophrenia and other psychiatric conditions. Proc Natl Acad Sci U S A 101:8180-8185. CrossRef Medline

Klein I, Cornejo JC, Polakos NK, John B, Wuensch SA, Topham DJ, Pierce RH, Crispe IN (2007) Kupffer cell heterogeneity: functional properties of bone marrow derived and sessile hepatic macrophages. Blood 110: 4077-4085. CrossRef Medline

Kokaia Z, Martino G, Schwartz M, Lindvall O (2012) Cross-talk between neural stem cells and immune cells: the key to better brain repair? Nat Neurosci 15:1078-1087. CrossRef Medline

Koyama Y, Tsujikawa K, Matsuda T, Baba A (2003) Endothelin-1 stimulates glial cell line-derived neurotrophic factor expression in cultured rat astrocytes. Biochem Biophys Res Commun 303:1101-1105. CrossRef Medline

Koyama Y, Baba A, Matsuda T (2005) Endothelins stimulate the expression of neurotrophin-3 in rat brain and rat cultured astrocytes. Neuroscience 136:425-433. CrossRef Medline
Kumar H, Kawai T, Akira S (2011) Pathogen recognition by the innate immune system. Int Rev Immunol 30:16-34. CrossRef Medline

Kunis G, Baruch K, Rosenzweig N, Kertser A, Miller O, Berkutzki T (2013) IFN- $\gamma$-dependent activation of the brain's choroid plexus for CNS immune surveillance and repair. Brain. In press.

Lampron A, Gosselin D, Rivest S (2011) Targeting the hematopoietic system for the treatment of Alzheimer's disease. Brain Behav Immun 25 [Suppl 1]:S71-S79.

Lampron A, Lessard M, Rivest S (2012) Effects of myeloablation, peripheral chimerism, and whole-body irradiation on the entry of bone marrowderived cells into the brain. Cell Transplant 21:1149-1159. CrossRef Medline

Landreth GE, Reed-Geaghan EG (2009) Toll-like receptors in Alzheimer's disease. Curr Top Microbiol Immunol 336:137-153. CrossRef Medline

Lee CY, Landreth GE (2010) The role of microglia in amyloid clearance from the AD brain. J Neural Transm 117:949-960. CrossRef Medline

Lindvall O, Kokaia Z (2010) Stem cells in human neurodegenerative disorders: time for clinical translation? J Clin Invest 120:29-40. CrossRef Medline

Lippoldt A, Liebner S, Andbjer B, Kalbacher H, Wolburg H, Haller H, Fuxe K (2000) Organization of choroid plexus epithelial and endothelial cell tight junctions and regulation of claudin-1, -2 and -5 expression by protein kinase C. Neuroreport 11:1427-1431. CrossRef Medline

Livesey FJ (1999) Netrins and netrin receptors. Cell Mol Life Sci 56:62-68. CrossRef Medline

Lu Z, Elliott MR, Chen Y, Walsh JT, Klibanov AL, Ravichandran KS, Kipnis J (2011) Phagocytic activity of neuronal progenitors regulates adult neurogenesis. Nat Cell Biol 13:1076-1083. CrossRef Medline

Maarsingh H (2008) Arginase: a novel key enzyme in asthma. Fund Clin Pharmacol 22:14.

Majumdar A, Cruz D, Asamoah N, Buxbaum A, Sohar I, Lobel P, Maxfield FR (2007) Activation of microglia acidifies lysosomes and leads to degradation of Alzheimer amyloid fibrils. Mol Biol Cell 18:1490-1496. CrossRef Medline

Martinez FO, Sica A, Mantovani A, Locati M (2008) Macrophage activation and polarization. Front Biosci 13:453-461. CrossRef Medline

Martino G, Pluchino S, Bonfanti L, Schwartz M (2011) Brain regeneration in physiology and pathology: the immune signature driving therapeutic plasticity of neural stem cells. Physiol Rev 91:1281-1304. CrossRef Medline

McGeer PL, Schulzer M, McGeer EG (1996) Arthritis and antiinflammatory agents as possible protective factors for Alzheimer's disease: a review of 17 epidemiologic studies. Neurology 47:425-432. CrossRef Medline

Michaud JP, Richard KL, Rivest S (2012) Hematopoietic MyD88-adaptor protein acts as a natural defense mechanism for cognitive deficits in Alzheimer's disease. Stem Cell Rev 8:898-904. CrossRef Medline

Michaud JP, Halle M, Lampron A, Theriault P, Prefontaine P, Filali M, Tribout-Jover P, Lanteigne AM, Jodoin R, Cluff C, Brichard V, Palmantier R, Pilorget A, Larocque D, Rivest S (2013) Toll-like receptor 4 stimulation with the detoxified ligand monophosphoryl lipid A improves Alzheimer's disease-related pathology. Proc Natl Acad Sci U S A 110: 1941-1946. CrossRef Medline

Minoretti P, Gazzaruso C, Vito CD, Emanuele E, Bianchi M, Coen E, Reino M, Geroldi D (2006) Effect of the functional toll-like receptor 4 Asp299Gly polymorphism on susceptibility to late-onset Alzheimer's disease. Neurosci Lett 391:147-149. CrossRef Medline

Mizee MR, Wooldrik D, Lakeman KA, van het Hof B, Drexhage JA, Geerts D, Bugiani M, Aronica E, Mebius RE, Prat A, de Vries HE, Reijerkerk A (2013) Retinoic acid induces blood-brain barrier development. J Neurosci 33:1660-1671. CrossRef Medline

Moalem G, Leibowitz-Amit R, Yoles E, Mor F, Cohen IR, Schwartz M (1999) Autoimmune $\mathrm{T}$ cells protect neurons from secondary degeneration after central nervous system axotomy. Nat Med 5:49-55. CrossRef Medline

Monje ML, Toda H, Palmer TD (2003) Inflammatory blockade restores adult hippocampal neurogenesis. Science 302:1760-1765. CrossRef Medline

Montgomery SL, Mastrangelo MA, Habib D, Narrow WC, Knowlden SA, Wright TW, Bowers WJ (2011) Ablation of TNF-RI/RII expression in Alzheimer's disease mice leads to an unexpected enhancement of pathology: implications for chronic pan-TNF- $\alpha$ suppressive therapeutic strategies in the brain. J Pathol 179:2053-2070. CrossRef Medline 
Moraes CF, Lins TC, Carmargos EF, Naves JO, Pereira RW, Nóbrega OT (2012) Lessons from genome-wide association studies findings in Alzheimer's disease. Psychogeriatrics 12:62-73. CrossRef Medline

Naert G, Rivest S (2011) CC chemokine receptor 2 deficiency aggravates cognitive impairments and amyloid pathology in a transgenic mouse model of Alzheimer's disease. J Neurosci 31:6208-6220. CrossRef Medline

Okun E, Griffioen K, Barak B, Roberts NJ, Castro K, Pita MA, Cheng A, Mughal MR, Wan R, Ashery U, Mattson MP (2010) Toll-like receptor 3 inhibits memory retention and constrains adult hippocampal neurogenesis. Proc Natl Acad Sci U S A 107:15625-15630. CrossRef Medline

Rapalino O, Lazarov-Spiegler O, Agranov E, Velan GJ, Yoles E, Fraidakis M, Solomon A, Gepstein R, Katz A, Belkin M, Hadani M, Schwartz M (1998) Implantation of stimulated homologous macrophages results in partial recovery of paraplegic rats. Nat Med 4:814-821. CrossRef Medline

Ray S, Britschgi M, Herbert C, Takeda-Uchimura Y, Boxer A, Blennow K, Friedman LF, Galasko DR, Jutel M, Karydas A, Kaye JA, Leszek J, Miller BL, Minthon L, Quinn JF, Rabinovici GD, Robinson WH, Sabbagh MN, So YT, Sparks DL, et al. (2007) Classification and prediction of clinical Alzheimer's diagnosis based on plasma signaling proteins. Nat Med 13: 1359-1362. CrossRef Medline

Reed-Geaghan EG, Savage JC, Hise AG, Landreth GE (2009) CD14 and tolllike receptors 2 and 4 are required for fibrillar $A \beta$-stimulated microglial activation. J Neurosci 29:11982-11992. CrossRef Medline

Reuss B, Dono R, Unsicker K (2003) Functions of fibroblast growth factor (FGF)-2 and FGF-5 in astroglial differentiation and blood-brain barrier permeability: evidence from mouse mutants. J Neurosci 23:6404-6412. Medline

Reynolds AD, Stone DK, Hutter JA, Benner EJ, Mosley RL, Gendelman HE (2010) Regulatory T cells attenuate Th17 cell-mediated nigrostriatal dopaminergic neurodegeneration in a model of Parkinson's disease. J Immunol 184:2261-2271. CrossRef Medline

Richard KL, Filali M, Préfontaine P, Rivest S (2008) Toll-like receptor 2 acts as a natural innate immune receptor to clear amyloid beta 1-42 and delay the cognitive decline in a mouse model of Alzheimer's disease. J Neurosci 28:5784-5793. CrossRef Medline

Rink L, Cakman I, Kirchner H (1998) Altered cytokine production in the elderly. Mech Ageing Dev 102:199-209. CrossRef Medline

Rolls A, Shechter R, London A, Ziv Y, Ronen A, Levy R, Schwartz M (2007) Toll-like receptors modulate adult hippocampal neurogenesis. Nat Cell Biol 9:1081-1088. CrossRef Medline

Rolls A, Shechter R, London A, Segev Y, Jacob-Hirsch J, Amariglio N, Rechavi G, Schwartz M (2008) Two faces of chondroitin sulfate proteoglycan in spinal cord repair: a role in microglia/macrophage activation. PLoS Med 5:e171. CrossRef Medline

Rolls A, Shechter R, Schwartz M (2009) The bright side of the glial scar in CNS repair. Nat Rev Neurosci 10:235-241. CrossRef Medline

Ron-Harel N, Segev Y, Lewitus GM, Cardon M, Ziv Y, Netanely D, JacobHirsch J, Amariglio N, Rechavi G, Domany E, Schwartz M (2008) Agedependent spatial memory loss can be partially restored by immune activation. Rejuvenation Res 11:903-913. CrossRef Medline

Ron-Harel N, Cardon M, Schwartz M (2011) Brain homeostasis is maintained by "danger" signals stimulating a supportive immune response within the brain's borders. Brain Behav Immun 25:1036-1043. CrossRef Medline

Rubio-Perez JM, Morillas-Ruiz JM (2012) A review: inflammatory process in Alzheimer's disease, role of cytokines. Sci World J 2012:756357. CrossRef Medline

Schafer DP, Lehrman EK, Kautzman AG, Koyama R, Mardinly AR, Yamasaki R, Ransohoff RM, Greenberg ME, Barres BA, Stevens B (2012) Microglia sculpt postnatal neural circuits in an activity and complementdependent manner. Neuron 74:691-705. CrossRef Medline

Schilling M, Strecker JK, Schäbitz WR, Ringelstein EB, Kiefer R (2009) Effects of monocyte chemoattractant protein 1 on blood-borne cell recruitment after transient focal cerebral ischemia in mice. Neuroscience 161: 806-812. CrossRef Medline

Schwartz M, Cohen IR (2000) Autoimmunity can benefit self-maintenance. Immunol Today 21:265-268. CrossRef Medline

Schwartz M, Shechter R (2010a) Systemic inflammatory cells fight off neurodegenerative disease. Nat Rev Neurol 6:405-410. CrossRef Medline

Schwartz M, Shechter R (2010b) Protective autoimmunity functions by in- tracranial immunosurveillance to support the mind: the missing link between health and disease. Mol Psychiatry 15:342-354. CrossRef Medline

Schwartz M, Moalem G, Leibowitz-Amit R, Cohen IR (1999) Innate and adaptive immune responses can be beneficial for CNS repair. Trends Neurosci 22:295-299. CrossRef Medline

Serpe CJ, Coers S, Sanders VM, Jones KJ (2003) CD4+ T, but not CD8 + or $\mathrm{B}$, lymphocytes mediate facial motoneuron survival after facial nerve transection. Brain Behav Immun 17:393-402. CrossRef Medline

Shearer GM (1997) Th1/Th2 changes in aging. Mech Ageing Dev 94:1-5. CrossRef Medline

Shechter R, Schwartz M (2013a) CNS sterile injury: just another wound healing? Trends Mol Med 19:135-143. CrossRef Medline

Shechter R, Schwartz M (2013b) Harnessing monocyte-derived macrophages to control central nervous system pathologies: no longer 'if but 'how.' J Pathol 229:332-346. CrossRef

Shechter R, London A, Varol C, Raposo C, Cusimano M, Yovel G, Rolls A, Mack M, Pluchino S, Martino G, Jung S, Schwartz M (2009) Infiltrating blood-derived macrophages are vital cells playing an anti-inflammatory role in recovery from spinal cord injury in mice. PLoS Med 6:e1000113. CrossRef Medline

Shechter R, Raposo C, London A, Sagi I, Schwartz M (2011) The glial scarmonocyte interplay: a pivotal resolution phase in spinal cord repair. PLoS One 6:e27969. CrossRef Medline

Shechter R, London A, Schwartz M (2013a) Orchestrated leukocyte recruitment to immune-privileged sites: absolute barriers versus educational gates. Nat Rev Immunol 13:206-218. CrossRef Medline

Shechter R, Miller O, Yovel G, Rosenzweig N, London A, Ruckh J, Kim KW, Klein E, Kalchenko V, Bendel P, Lira SA, Jung S, Schwartz M (2013b) Recruitment of beneficial M2 macrophages to injured spinal cord is orchestrated by remote brain choroid plexus. Immunity 38:555-569. CrossRef Medline

Silver J, Miller JH (2004) Regeneration beyond the glial scar. Nat Rev Neurosci 5:146-156. CrossRef Medline

Simard AR, Rivest S (2004) Bone marrow stem cells have the ability to populate the entire central nervous system into fully differentiated parenchymal microglia. FASEB J 18:998-1000. CrossRef Medline

Song M, Jin J, Lim JE, Kou J, Pattanayak A, Rehman JA, Kim HD, Tahara K, Lalonde R, Fukuchi K (2011) TLR4 mutation reduces microglial activation, increases Abeta deposits and exacerbates cognitive deficits in a mouse model of Alzheimer's disease. J Neuroinflammation 8:92. CrossRef Medline

Soulet D, Rivest S (2008a) Bone-marrow-derived microglia: myth or reality? Curr Opin Pharmacol 8:508-518. CrossRef Medline

Soulet D, Rivest S (2008b) Microglia. Curr Biol 18:R506-R508. CrossRef Medline

Stewart CR, Stuart LM, Wilkinson K, van Gils JM, Deng J, Halle A, Rayner KJ, Boyer L, Zhong R, Frazier WA, Lacy-Hulbert A, El Khoury J, Golenbock DT, Moore KJ (2010) CD36 ligands promote sterile inflammation through assembly of a Toll-like receptor 4 and 6 heterodimer. Nat Immunol 11:155-161. CrossRef Medline

Tahara K, Kim HD, Jin JJ, Maxwell JA, Li L, Fukuchi K (2006) Role of toll-like receptor signalling in Abeta uptake and clearance. Brain 129: 3006-3019. CrossRef Medline

Takahashi K, Rochford CD, Neumann H (2005) Clearance of apoptotic neurons without inflammation by microglial triggering receptor expressed on myeloid cells-2. J Exp Med 201:647-657. CrossRef Medline

Thrash JC, Torbett BE, Carson MJ (2009) Developmental regulation of TREM2 and DAP12 expression in the murine CNS: implications for Nasu-Hakola disease. Neurochem Res 34:38-45. CrossRef Medline

Town T, Laouar Y, Pittenger C, Mori T, Szekely CA, Tan J, Duman RS, Flavell RA (2008) Blocking TGF-beta-Smad2/3 innate immune signaling mitigates Alzheimer-like pathology. Nat Med 14:681-687. CrossRef Medline

Tremblay MÈ, Stevens B, Sierra A, Wake H, Bessis A, Nimmerjahn A (2011) The role of microglia in the healthy brain. J Neurosci 31:16064-16069. CrossRef Medline

Uchihara T, Akiyama H, Kondo H, Ikeda K (1997) Activated microglial cells are colocalized with perivascular deposits of amyloid-beta protein in Alzheimer's disease brain. Stroke 28:1948-1950. CrossRef Medline

Udan ML, Ajit D, Crouse NR, Nichols MR (2008) Toll-like receptors 2 and 4 mediate Abeta(1-42) activation of the innate immune response in a human monocytic cell line. J Neurochem 104:524-533. CrossRef Medline Vaknin I, Kunis G, Miller O, Butovsky O, Bukshpan S, Beers DR, Henkel JS, 
Yoles E, Appel SH, Schwartz M (2011) Excess circulating alternatively activated myeloid (M2) cells accelerate ALS progression while inhibiting experimental autoimmune encephalomyelitis. PLoS One 6:e26921. CrossRef Medline

van Assema DM, Lubberink M, Bauer M, van der Flier WM, Schuit RC, Windhorst AD, Comans EF, Hoetjes NJ, Tolboom N, Langer O, Müller M, Scheltens P, Lammertsma AA, van Berckel BN (2012) Blood-brain barrier P-glycoprotein function in Alzheimer's disease. Brain 135:181189. CrossRef Medline

Villeda SA, Luo J, Mosher KI, Zou B, Britschgi M, Bieri G, Stan TM, Fainberg N, Ding Z, Eggel A, Lucin KM, Czirr E, Park JS, Couillard-Després S, Aigner L, Li G, Peskind ER, Kaye JA,Quinn JF, Galasko DR, et al. (2011) The ageing systemic milieu negatively regulates neurogenesis and cognitive function. Nature 477:90-94. CrossRef Medline

Villeda SA, Wyss-Coray T (2013) The circulatory systemic environment as a modulator of neurogenesis and brain aging. Autoimmun Rev 12:674677. CrossRef Medline

Wall MJ (2003) Endogenous nitric oxide modulates GABAergic transmission to granule cells in adult rat cerebellum. Eur J Neurosci 18:869-878. CrossRef Medline

Wang LZ, Yu JT, Miao D, Wu ZC, Zong Y, Wen CQ, Tan L (2011) Genetic association of TLR4/11367 polymorphism with late-onset Alzheimer's disease in a Han Chinese population. Brain Res 1381:202-207. CrossRef Medline

Westin K, Buchhave P, Nielsen H, Minthon L, Janciauskiene S, Hansson O (2012) CCL2 is associated with a faster rate of cognitive decline during early stages of Alzheimer's disease. PLoS One 7:e30525. CrossRef Medline

Wolburg H, Lippoldt A (2002) Tight junctions of the blood-brain barrier: development, composition and regulation. Vasc Pharmacol 38:323-337. CrossRef Medline

Wolf SA, Steiner B, Akpinarli A, Kammertoens T, Nassenstein C, Braun A, Blankenstein T, Kempermann G (2009) CD4-positive T lymphocytes provide a neuroimmunological link in the control of adult hippocampal neurogenesis. J Immunol 182:3979-3984. CrossRef Medline

Wosik K, Cayrol R, Dodelet-Devillers A, Berthelet F, Bernard M, Moumdjian R, Bouthillier A, Reudelhuber TL, Prat A (2007) Angiotensin II controls occludin function and is required for blood brain barrier maintenance: relevance to multiple sclerosis. J Neurosci 27:9032-9042. CrossRef Medline

Wu HH, Bellmunt E, Scheib JL, Venegas V, Burkert C, Reichardt LF, Zhou Z, Fariñas I, Carter BD (2009) Glial precursors clear sensory neuron corpses during development via Jedi-1, an engulfment receptor. Nat Neurosci 12:1534-1541. CrossRef Medline

Wurmser AE, Palmer TD, Gage FH (2004) Neuroscience: cellular interactions in the stem cell niche. Science 304:1253-1255. CrossRef Medline

Xiong H, Callaghan D, Jones A, Bai J, Rasquinha I, Smith C, Pei K, Walker D, Lue LF, Stanimirovic D, Zhang W (2009) ABCG2 is upregulated in Alzheimer's brain with cerebral amyloid angiopathy and may act as a gatekeeper at the blood-brain barrier for Abeta(1-40) peptides. J Neurosci 29:5463-5475. CrossRef Medline

Yin Y, Henzl MT, Lorber B, Nakazawa T, Thomas TT, Jiang F, Langer R, Benowitz LI (2006) Oncomodulin is a macrophage-derived signal for axon regeneration in retinal ganglion cells. Nat Neurosci 9:843-852. CrossRef Medline

Yoles E, Hauben E, Palgi O, Agranov E, Gothilf A, Cohen A, Kuchroo V, Cohen IR, Weiner H, Schwartz M (2001) Protective autoimmunity is a physiological response to CNS trauma. J Neurosci 21:3740-3748. Medline

Yong VW, Rivest S (2009) Taking advantage of the systemic immune system to cure brain diseases. Neuron 64:55-60. CrossRef Medline

Yu JT, Miao D, Cui WZ, Ou JR, Tian Y, Wu ZC, Zhang W, Tan L (2012) Common variants in toll-like receptor 4 confer susceptibility to Alzheimer's disease in a Han Chinese population. Curr Alzheimer Resh 9:458 466. CrossRef Medline

Zhang W, Wang LZ, Yu JT, Chi ZF, Tan L (2012) Increased expressions of TLR2 and TLR4 on peripheral blood mononuclear cells from patients with Alzheimer's disease. J Neurol Sci 315:67-71. CrossRef Medline

Ziv Y, Schwartz M (2008) Immune-based regulation of adult neurogenesis: implications for learning and memory. Brain Behav Immun 22:167-176. CrossRef Medline

Ziv Y, Ron N, Butovsky O, Landa G, Sudai E, Greenberg N, Cohen H, Kipnis J, Schwartz M (2006) Immune cells contribute to the maintenance of neurogenesis and spatial learning abilities in adulthood. Nat Neurosci 9:268-275. CrossRef Medline

Zlokovic BV (2011) Neurovascular pathways to neurodegeneration in Alzheimer's disease and other disorders. Nat Rev Neurosci 12:723-738. CrossRef Medline

Zoghbi HY (2002) Introduction: Rett syndrome. Ment Retard Dev Disabil Res Rev 8:59-60. CrossRef Medline

Zoghbi HY (2005) MeCP2 dysfunction in humans and mice. J Child Neurol 20:736-740. CrossRef Medline 